\title{
Inhibition of Henipavirus fusion and infection by heptad-derived peptides of the Nipah virus fusion glycoprotein Katharine N Bossart ${ }^{\dagger 2}$, Bruce A Mungall ${ }^{\dagger 1}$, Gary Crameri ${ }^{1}$, Lin-Fa Wang1, Bryan T Eaton ${ }^{1}$ and Christopher C Broder*2
}

\author{
Address: ${ }^{1}$ CSIRO Livestock Industries, Australian Animal Health Laboratory, Geelong, Victoria 3220, Australia and ${ }^{2}$ Department of Microbiology \\ and Immunology, Uniformed Services University, Bethesda, MD 20814, USA \\ Email: Katharine N Bossart - Katharine.Bossart@csiro.au; Bruce A Mungall - Bruce.Mungall@csiro.au; Gary Crameri - Gary.Crameri@csiro.au; \\ Lin-Fa Wang - Linfa.Wang@csiro.au; Bryan T Eaton - Bryan.Eaton@csiro.au; Christopher C Broder* - cbroder@usuhs.mil \\ * Corresponding author †Equal contributors
}

Published: 18 July 2005

Virology Journal 2005, 2:57 doi:10.1186/1743-422X-2-57

This article is available from: http://www.virologyj.com/content/2/l/57

(c) 2005 Bossart et al; licensee BioMed Central Ltd.

This is an Open Access article distributed under the terms of the Creative Commons Attribution License (http://creativecommons.org/licenses/by/2.0), which permits unrestricted use, distribution, and reproduction in any medium, provided the original work is properly cited.
Received: 24 May 2005

Accepted: 18 July 2005

\begin{abstract}
Background: The recent emergence of four new members of the paramyxovirus family has heightened the awareness of and re-energized research on new and emerging diseases. In particular, the high mortality and person to person transmission associated with the most recent Nipah virus outbreaks, as well as the very recent re-emergence of Hendra virus, has confirmed the importance of developing effective therapeutic interventions. We have previously shown that peptides corresponding to the C-terminal heptad repeat (HR-2) of the fusion envelope glycoprotein of Hendra virus and Nipah virus were potent inhibitors of both Hendra virus and Nipah virus-mediated membrane fusion using recombinant expression systems. In the current study, we have developed shorter, second generation HR-2 peptides which include a capped peptide via amidation and acetylation and two poly(ethylene glycol)-linked (PEGylated) peptides, one with the PEG moity at the $\mathrm{C}$-terminus and the other at the $\mathrm{N}$-terminus. Here, we have evaluated these peptides as well as the corresponding scrambled peptide controls in Nipah virus and Hendra virusmediated membrane fusion and against infection by live virus in vitro.
\end{abstract}

Results: Unlike their predecessors, the second generation HR-2 peptides exhibited high solubility and improved synthesis yields. Importantly, both Nipah virus and Hendra virus-mediated fusion as well as live virus infection were potently inhibited by both capped and PEGylated peptides with $I_{50}$ concentrations similar to the original HR-2 peptides, whereas the scrambled modified peptides had no inhibitory effect. These data also indicate that these chemical modifications did not alter the functional properties of the peptides as inhibitors.

Conclusion: Nipah virus and Hendra virus infection in vitro can be potently blocked by specific HR-2 peptides. The improved synthesis and solubility characteristics of the second generation HR-2 peptides will facilitate peptide synthesis for pre-clinical trial application in an animal model of Henipavirus infection. The applied chemical modifications are also predicted to increase the serum half-life in vivo and should increase the chance of success in the development of an effective antiviral therapy. 


\section{Background}

Two novel zoonotic paramyxoviruses have emerged to cause disease in the past decade, Hendra virus $(\mathrm{HeV})$ in Australia in 1994-5 [1], and Nipah virus (NiV) in Malaysia in 1999 [2]. HeV and NiV caused severe respiratory and encephalitic disease in animals and humans (reviewed in $[3,4]), \mathrm{HeV}$ was transmitted to humans by close contact with infected horses; NiV was passed from infected pigs to humans. Both are unusual among the paramyxoviruses in their ability to infect and cause potentially fatal disease in a number of host species, including humans. Both viruses also have an exceptionally large genome and are genetically closely related yet distinct from all other paramyxovirus family members. Due to their unique genetic and biological properties, $\mathrm{HeV}$ and $\mathrm{NiV}$ have been classified as prototypic members of the new genus Henipavirus, in the family Paramyxoviridae $[5,6]$. Serological surveillance and virus isolation studies indicated that $\mathrm{HeV}$ and $\mathrm{NiV}$ reside naturally in flying foxes in the genus Pteropus (reviewed in [7]). Investigation of possible mechanisms precipitating their emergence indicates ecological changes resulting from deforestation, human encroachment into bat habitats and high intensity livestock farming practices as the likely primary factors [7]. Because these viruses are harboured in a mammalian reservoir whose range is vast, both $\mathrm{HeV}$ and $\mathrm{NiV}$ have the capability to cause disease over a large area and in new regions where disease was not seen previously. There have been several other suspected $\mathrm{NiV}$ occurrences since its recognition in 1999. Recently two confirmed outbreaks in 2004 in Bangladesh caused fatal encephalitis in humans and for the first time, personto-person transmission appeared to have been a primary mode of spread [8-12]. In addition, there appeared to be direct transmission of the virus from the flying fox to humans, and the case mortality rate was $~ 70 \%$; significantly higher than any other NiV outbreak to date. Currently, $\mathrm{HeV}$ and $\mathrm{NiV}$ are categorized as biological safety level-4 (BSL-4) pathogens, and NiV has also been classified as a category $\mathrm{C}$ priority pathogen. Category $\mathrm{C}$ agents include emerging pathogens that could be engineered for mass dissemination in the future because of availability; ease of production and dissemination; and potential for high morbidity and mortality and major health impact. All of the above reasons illustrate why an effective antiviral therapy is needed for henipaviruses.

Paramyxoviruses contain two membrane-anchored glycoproteins that are required for virion attachment to and fusion with the membrane of the host cell. Depending on the biological properties of the virus, the attachment protein is referred to as either the hemagglutinin-neuraminidase $(\mathrm{HN})$, the hemagglutinin $(\mathrm{H})$, or the $\mathrm{G}$ glycoprotein which lacks hemagglutinating and neuraminidase activities. Whereas most paramyxoviruses employ sialic acid moieties as receptors, $\mathrm{HeV}$ and NiV make use of a cell-sur- face expressed protein and their G glycoprotein binds to ephrin-B2 on host cells [13]. The fusion protein (F) facilitates the fusion of virion and host cell membranes during virus infection, and is an oligomeric homotrimer [14,15]. The biologically active F protein consists of two disulfide linked subunits, $\mathrm{F}_{1}$ and $\mathrm{F}_{2}$, which are generated by the proteolytic cleavage of a precursor polypeptide known as $\mathrm{F}_{0}$ (reviewed in $[16,17]$ ). In all cases the membraneanchored subunit, $\mathrm{F}_{1}$, contains a new amino terminus that is hydrophobic and highly conserved across virus families and referred to as the fusion peptide (reviewed in [18]). There have been considerable advances in the understanding of the structural features and development of mechanistic models of how several viral envelope glycoproteins function in driving the membrane fusion reaction (reviewed in [19-21]). One important feature of many of these fusion glycoproteins are two $\alpha$-helical domains referred to as heptad repeats (HR) that are involved in the formation of a trimer-of-hairpins structure [22,23]. HR-1 is located proximal to the amino $(\mathrm{N})$-terminal fusion peptide and HR-2 precedes the transmembrane domain near the carboxyl (C)-terminus [22,24-26]. For many viral fusion glycoproteins the N-terminal HR-1 forms an interior, trimeric coiled-coil surrounded by three anti-parallel helices formed from HR-2 (reviewed in [18]). Both the $\mathrm{HeV}$ and $\mathrm{NiV} \mathrm{F}$ glycoprotein $\mathrm{HR}$ domains have been shown to interact with each other and form the typical 6helix coiled-coil bundles [24,27].

Peptide sequences from either HR domain of the F glycoprotein of several paramyxoviruses, including $\mathrm{HeV}$ and $\mathrm{NiV}$ have been shown to be inhibitors of fusion $[25,28$ 35]. Targeting this membrane fusion step of the viral infection process has garnered much attention, primarily lead by work on human immunodeficiency virus type 1 (HIV-1) (reviewed in [36]). Indeed, the HIV-1 envelope derived peptide, enfuvirtide (Fuzeon ${ }^{\mathrm{TM}}$, formerly T-20), has been clinically successful $[37,38]$. Enfuvirtide is a 36amino acid peptide corresponding to a portion of the $\mathrm{C}$ terminal HR-2 domain of the gp41 subunit of the envelope glycoprotein. Approved by the FDA in March 2003, enfuvirtide has been shown to be comparable to other anti-retroviral therapeutics in terms of reducing viral load, and is generally well tolerated despite its parenteral administration, and enfuvirtide has added significantly to optimized combination therapy in a growing number of patients with multiple HIV-1 resistance to the currently available antiretroviral drugs [39].

No therapeutic treatments are currently available for $\mathrm{HeV}$ or NiV infection. In our previous studies, we demonstrated that peptides derived from the HR-2 of either the $\mathrm{HeV}$ or NiV F were potent inhibitors of fusion [34]. However, although these peptides were effective, their specific properties such as overall length where not optimized, 
and they were large and somewhat insoluble making synthesis and purification problematic. In preparation to evaluate these peptides as potential therapeutic fusion inhibitors against $\mathrm{NiV}$ and $\mathrm{HeV}$ infection, second generation versions were designed with changes aimed at improving their solubility and in vivo half-life when administered to animals. In the current study, we have produced shorter 36 amino acid capped peptides by amidation at the N-terminus and acetylation at the carboxylterminus. In addition, two alternate peptide versions were made with the addition of a poly(ethylene glycol) moiety to either the $\mathrm{C}$-terminus or the $\mathrm{N}$-terminus. Here we report on the biological activity of these modified peptides and demonstrate that chemical modification increased solubility significantly without altering their biological properties of inhibiting membrane fusion. Further, all three versions were capable of blocking both fusion as well as live $\mathrm{HeV}$ and $\mathrm{NiV}$ infection with $\mathrm{IC}_{50}$ concentrations in the $\mathrm{nM}$ range, similar to those reported with other viral systems.

\section{Results \\ Heptad peptide inhibition of Hendra virus and Nipah virus-mediated cell-cell fusion}

Hypothetical models of the transmembrane (F1) glycoproteins of $\mathrm{HeV}$ and $\mathrm{NiV}$ are shown in Fig. 1. The models are derived by homology modeling with the known structure of the F protein of Newcastle disease virus [40]. These models are consistent protein structures predicted by the computer algorithms PHDsec [41] and TMpred [42]. Overall, the structures of the $\mathrm{HeV}$ and $\mathrm{NiV} \mathrm{F}_{1}$ transmembrane subunit, including the heptad repeats (HR-1 and HR-2 helices), closely resemble that of the gp41 subunit of the HIV-1 envelope glycoprotein [43-45]. The depicted circle in the background represents the $\mathrm{F}_{2}$ subunit of $\mathrm{NiV}$ F. Due to the structural similarities and clinical success of the gp41 heptad peptides, we hypothesized that peptides derived from the HR-2 of $\mathrm{HeV}$ or NiV F would be effective antiviral therapies for henipavirus infection. In previous studies we evaluated the inhibition properties of 42 amino acid length peptides derived from both the $\mathrm{N}$ and C-terminal heptad repeats (HR-1 and HR-2) of HeV and $\mathrm{NiV} F$ in a vaccinia virus-based reporter gene assay that quantitatively measured cell-cell fusion mediated by the envelope glycoproteins of $\mathrm{HeV}$ and $\mathrm{NiV}[25,34]$. Although both HR-1 and HR-2 derived peptides exhibited fusion inhibitory activity, the HR-2 peptide (residues 447-489) was more potent and more soluble. The $\mathrm{HeV}$ and NiV HR2 peptides differed at three locations (amino acids 450, 479 and 480) with phenylalanine, arginine and leucine in $\mathrm{NiV}$ replaced by tyrosine, lysine and isoleucine in $\mathrm{HeV}$ $[6,46]$. These differences in the sequence of either peptide did not alter their homologous or heterologous inhibitory activity, suggesting that either peptide possessed potential therapeutic activity to both $\mathrm{HeV}$ and NiV. Here, we designed second generation versions of the NiV based HR2 derived peptide with changes aimed at improving their solubility and in vivo half-life when administered to animals. Shorter, 36 amino acid capped peptides were synthesized (sequence denoted as FC2 in Fig. 1) by amidation at the N-terminus and acetylation at the carboxyl-terminus, modifications known to have improved in vivo half-life of Fuzeon ${ }^{\mathrm{TM}}$ (Thomas Matthews, Trimeris Inc., personal communication). In addition, two alternate peptide versions were made with the addition of a poly(ethylene glycol) moiety to either the C-terminus or the N-terminus which improved peptide solubility during preparation, and may also potentially improve the pharmacokinetics in vivo $[47,48]$.

First, we examined the activity of the capped peptides on $\mathrm{HeV}$ and $\mathrm{NiV}$-mediated membrane fusion. In previous studies, un-capped heptad-derived peptides had to be dissolved initially in 100\% DMSO at concentrations between 50 and $500 \mu \mathrm{g} / \mathrm{ml}$ and then diluted in medium in order to maintain solubility. Here, the capped heptad-derived peptide (capped-NiV FC2) was completely soluble and dissolved in cell culture medium at concentrations as high as $10 \mathrm{mg} / \mathrm{ml}$. For cell-cell fusion, envelope expressing-effector cells were added to peptides prior to the addition of target cells. Shown in Fig. 2 are the dose-dependent inhibition profiles of $\mathrm{HeV}$ (column one) and NiV-mediated (column 2) cell-cell fusion mediated by the capped-NiV FC2 peptide in Vero (Fig. 2A), U373 (Fig. 2B), and PCI 13 (Fig. 2C) cell lines. The scrambled, capped, control peptide (capped-ScNiV FC2) had no inhibitory effect, over the same concentration range, on the cell-fusion mediated by either virus in any of the three cell lines. NiV-mediated fusion appeared to be slightly more sensitive to peptide inhibition in comparison to the cell-fusion activity of $\mathrm{HeV}$, although the calculated $\mathrm{IC}_{50}$ concentrations in each were comparable (Table 1 ). Importantly, the $\mathrm{IC}_{50}$ values of the capped version of NiV FC2 in these in vitro cell-cell fusion assays were within the $13-27 \mathrm{nM}$ range, similar to what was observed in prior studies utilizing un-capped versions of the 42 amino acid heptad-derived peptides which yielded $\mathrm{IC}_{50}$ values between 5.2 and $5.8 \mathrm{nM}$ [34].

Using the cell-cell fusion assay we next examined the PEGmodified versions of NiV FC2. As predicted, these pegylated heptad peptides also possessed increased solubility characteristics and could be readily prepared at concentrations up to $10 \mathrm{mg} / \mathrm{ml}$. The dose-response inhibition results of the N-PEG-NiV FC2 and C-PEG-NiV FC2 peptides are shown in Fig. 3, and inhibition was demonstrated in Vero (Fig. 3A), U373 (Fig. 3B), and PCI 13 (Fig. 3C) cell lines. Both pegylated versions of NiV FC2 were capable of blocking $\mathrm{NiV}$ and $\mathrm{HeV}$-mediated cell-fusion, while the scrambled PEG-control peptide (C-PEG-ScNiV FC2) had no inhibitory activity. Because of the required 


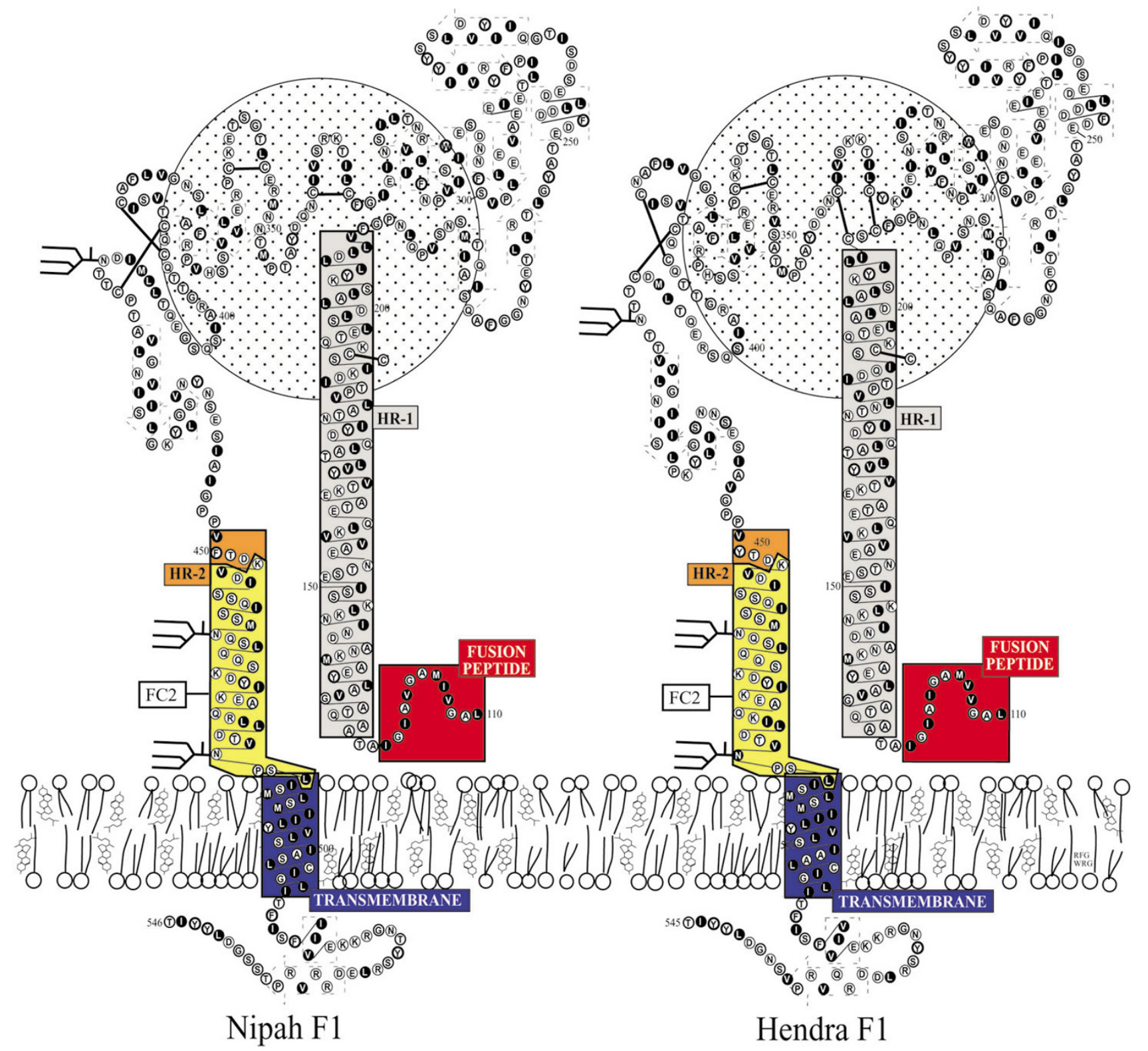

Figure I

Hypothetical models of the transmembrane (FI) glycoproteins of Hendra virus and Nipah virus. The models are derived by homology modeling with the known structure of the F protein of Newcastle disease virus [40]. These models are consistent protein structures predicted by the computer algorithms PHDsec [4I] and TMpred [42] as described in the Methods. The heptad repeats are indicated as HR-I (grey) and HR-2 (yellow/orange), transmembrane anchor (blue). The $F_{2}$ subunit

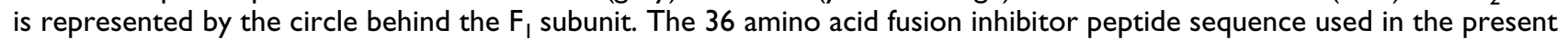
study is designated as FC2 and is boxed (yellow). The equivalent location of FC2 in the HeV FI subunit is shown for comparison.

specificity of the heptad peptide amino acid sequence to convey fusion inhibitory activity, as well as the high cost of peptide synthesis, we chose to only synthesize one ver- sion of the scrambled peptide as a pegylated control with the $\mathrm{PEG}_{10}$ moiety linked to the C-terminus. It was also noted that the NiV FC2 peptide with the $\mathrm{PEG}_{10}$ moiety 

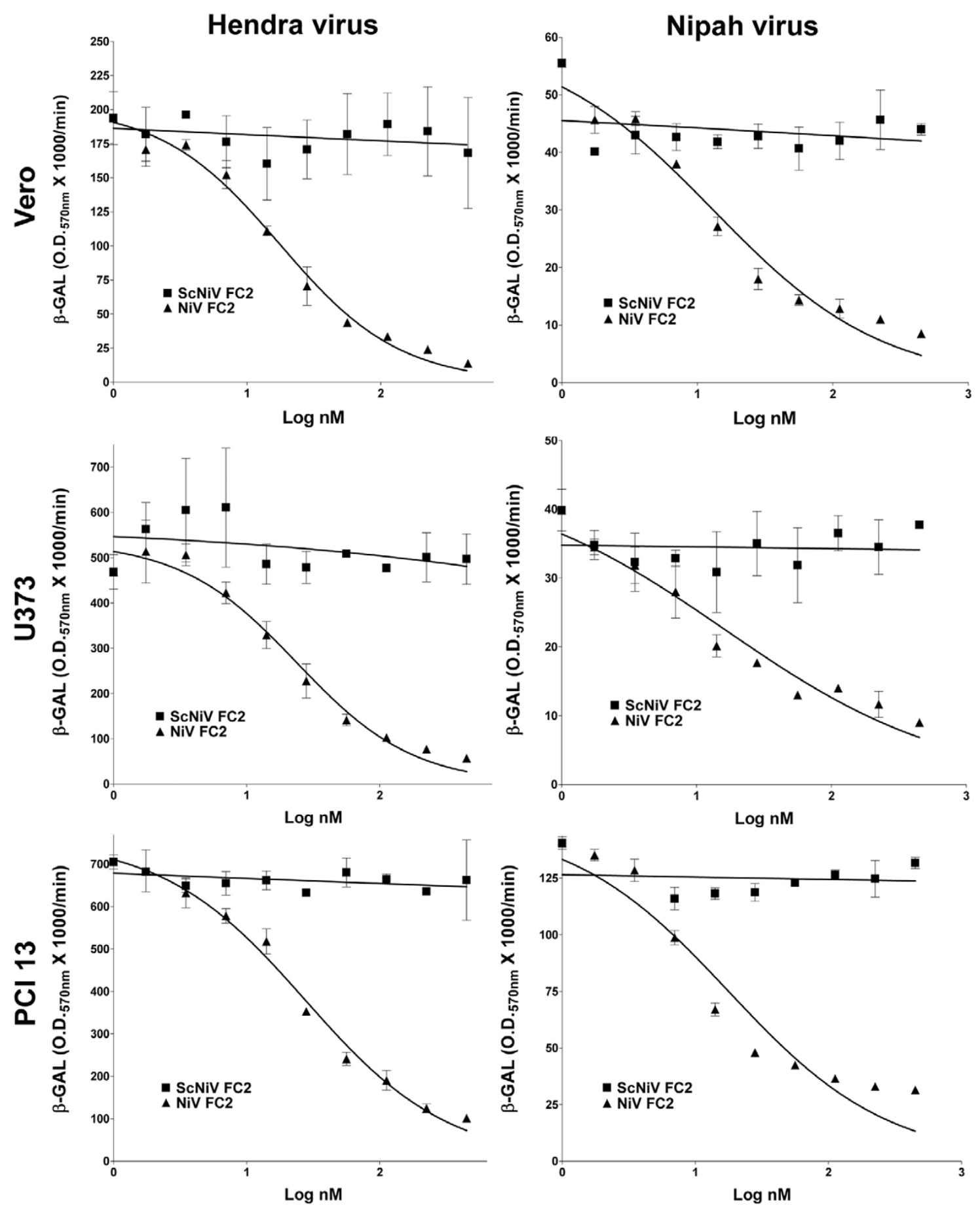

\section{Figure 2}

Inhibition of Hendra virus and Nipah virus-mediated cell-cell fusion by capped C-terminal heptad peptide NiV FC2. HeLa cells were infected with vaccinia recombinants encoding HeV F and HeV G or NiV F and NiV G glycoproteins, along with a vaccinia recombinant encoding T7 RNA polymerase (effector cells). Each designated target cell type was infected with the $E$. coli LacZ-encoding reporter vaccinia virus vCB2IR. Each target cell type $\left(I \times 10^{5}\right)$ was plated in duplicate wells of a 96-well plate. Inhibition was carried out using either capped NiV FC2 or ScNiV FC2 (control) heptad peptide. Peptides were added to the $\mathrm{HeV}$ or NiV glycoprotein-expressing cells $\left(\mathrm{I} \times 10^{5}\right)$, incubated for $30 \mathrm{~min}$ at $37^{\circ} \mathrm{C}$, and then each target cell type was added. The cell fusion assay was performed for $2.5 \mathrm{hr}$ at $37^{\circ} \mathrm{C}$, followed by lysis in Nonidet P-40 (I \%) and $\beta$-Gal activity was quantified. 
Table I: Summary of $\mathbf{5 0 \%}$ inhibitory concentration values of peptide fusion inhibitors in cell-cell fusion and virus infection assays.

\begin{tabular}{|c|c|c|c|c|c|}
\hline & Virus & Cell line & $\mathrm{IC}_{50} *$ Capped NiV FC2 (nM) & $\mathrm{IC}_{50} \mathrm{~N}-\mathrm{PEG}$ NiV FC2 (nM) & $\mathrm{IC}_{50}$ C-PEG NiV FC2 (nM) \\
\hline \multirow[t]{6}{*}{ Fusion Inhibition } & $\mathrm{HeV}$ & Vero & 17.59 & 6.54 & 142.4 \\
\hline & $\mathrm{NiV}$ & Vero & 13.08 & 3.66 & 98.05 \\
\hline & $\mathrm{HeV}$ & U373 & 23.91 & 9.71 & 78.07 \\
\hline & $\mathrm{NiV}$ & U373 & 16.28 & 4.85 & 79.19 \\
\hline & $\mathrm{HeV}$ & $\mathrm{PCl} 13$ & 27.54 & 6.18 & 147.2 \\
\hline & $\mathrm{NiV}$ & $\mathrm{PCl} 13$ & 17.79 & 5.04 & 93.32 \\
\hline \multirow[t]{4}{*}{ Live virus Inhibition } & $\mathrm{HeV}$ & Vero & 4.17 & 0.46 & 14.28 \\
\hline & $\mathrm{NiV}$ & Vero & 11.42 & 1.36 & 43.76 \\
\hline & $\mathrm{HeV}$ & $\mathrm{PCl} 13$ & 53.51 & 2.05 & 11.94 \\
\hline & $\mathrm{NiV}$ & $\mathrm{PCl} 13$ & 2.70 & 1.26 & 55.57 \\
\hline
\end{tabular}

*All IC $\mathrm{C}_{50} \mathrm{~s}$ were calculated using the non-linear regression function of GraphPad Prism software.

added to the C-terminus had significantly reduced inhibitory capacity, as compared to $\mathrm{PEG}_{10}$ added to the N-terminus, against both $\mathrm{NiV}$ and $\mathrm{HeV}$-mediated cell-fusion in all three cell lines tested. The reduction of C-PEG-NiV FC2 activity versus N-PEG-NiV FC2 was approximately 20 -fold in all cases (Table 1) with the exception of HeV-mediated cell-fusion with the U373 cell line (Fig. 3B). Importantly, in all cases, the N-PEG-NiV FC2 demonstrated very similar $\mathrm{IC}_{50} \mathrm{~s}(3-10 \mathrm{nM})$ to what was observed in prior studies utilizing un-capped versions of the 42 amino acid heptadderived peptides (5-6 $\mathrm{nM}$ ).

\section{Heptad peptide inhibition of Hendra virus and Nipah virus infection}

We next sought to confirm the inhibitory activity of Nipah virus heptad-derived peptides on the infection of live $\mathrm{HeV}$ and NiV in cell culture. We routinely employ Vero cell culture to perform live henipavirus infection assays, as well as in the propagation of virus stocks. The infection of Vero cells with $\mathrm{HeV}$ or $\mathrm{NiV}$ produced characteristic syncytial morphologies for each virus [49]. HeV reproducibly incorporated surrounding cells in the culture monolayer into each syncytium with the cell nuclei and viral proteins spread throughout the majority of the giant cell. In contrast, NiV infected syncytia initially demonstrated a similar appearance to their $\mathrm{HeV}$ counterparts, but characteristically both cell nuclei and viral protein were later sequestered around the periphery of each giant cell leaving the central region largely empty. In order to assess the extent of viral infection, we have developed an assay that will detect viral protein by immunofluorescence staining and localization of the P protein using a crossreactive anti-P peptide-specific antiserum. Using this syncytia-based immunofluorescence infection assay, we initially tested the N-PEG NiV FC2 peptide for its ability to block virus infection and results are shown in Fig. 4. In the absence of peptide, the different syncytial morphologies of $\mathrm{HeV}$ and $\mathrm{NiV}$ - infected cells were clearly evident. In the $\mathrm{HeV}$-infected syncytia (Fig. 4A), the viral P protein was spread throughout the majority of the giant cell; whereas, the NiV-infected syncytia (Fig. 4D) were circular structures delineated by a ring of the viral antigen. Incubation of 500 nM N-PEG-NiV FC2 with either HeV (Fig. 4B) or NiV (Fig. $4 \mathrm{E}$ ) infected cells resulted in a dramatic and robust reduction in syncytial size although the number of syncytia per cell monolayer remained largely unchanged. In parallel, the incubation of $500 \mathrm{nM}$ C-PEG-ScNiV FC2 control peptide with $\mathrm{HeV}$ or NiV-infected cells (Fig. 4C and $4 \mathrm{~F}$ respectively) revealed a syncytial morphology and size identical to those observed in the absence of any peptide.

We next used the syncytia-based immunofluorescence infection assay to examine all of the peptides over a range of concentrations in two different cell lines. We further preformed a quantitative analysis of syncytial areas based on immunofluorescence detection of viral antigen for $\mathrm{HeV}$ and NiV (see Materials and Methods) and revealed a grading of syncytial area inversely proportional to peptide concentration. Shown in Fig. 5 is the quantitative analysis of the syncytial area observed in $\mathrm{HeV}$ and $\mathrm{NiV}$ infection of both Vero (Fig. 5A and 5B) and PCI 13 (Fig. 5C and 5D) cell cultures over a range of concentrations of the capped$\mathrm{NiV}$ FC2 peptide. In all cases significant inhibition of $\mathrm{HeV}$ and $\mathrm{NiV}$ infection and spread is observed in comparison to the scrambled capped control peptide (capped-ScNiV FC2). Similarly, shown in Fig. 6, both the N-PEG and CPEG NiV FC2 peptides possessed potent inhibitory activity on $\mathrm{HeV}$ and $\mathrm{NiV}$ infection in Vero (Fig. 6A and 6B) and PCI 13 (Fig. 6C and 6D) cell cultures. Again, the scrambled C-PEG control peptide (C-PEG-ScNiV FC2) had no effect at any concentration tested. As was observed in the cell-cell fusion assays, in all cases, the C-PEG-NiV FC2 peptide exhibited weaker inhibitory activity in blocking virus infection, spread and syncytial size in comparison to 

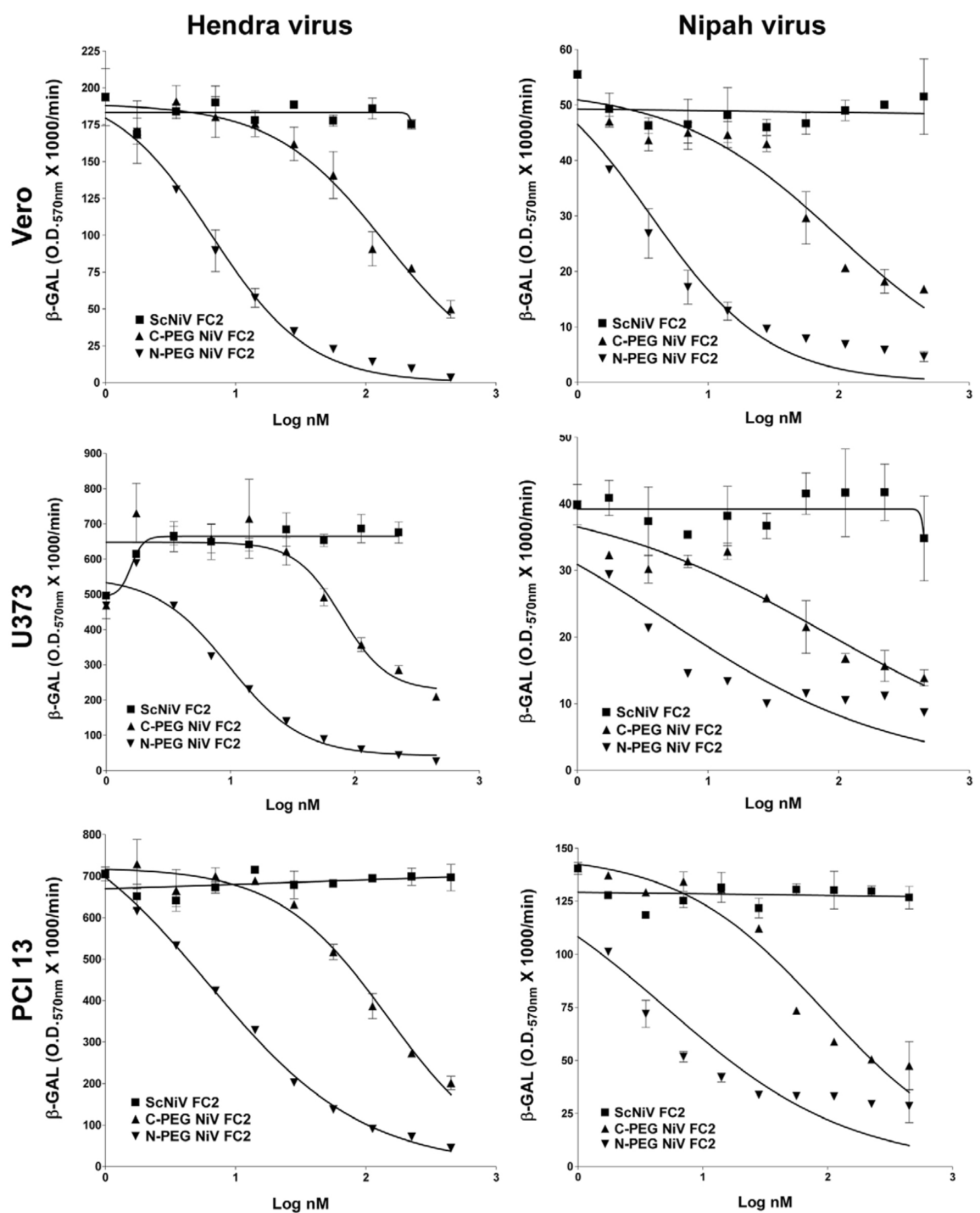

Figure 3

Inhibition of Hendra virus and Nipah virus-mediated cell-cell fusion by $\mathbf{N}$-terminal and $\mathbf{C}$-terminal (PEG $\left.{ }_{10}\right)$ pegylated heptad peptide NiV FC2. HeLa cells were infected with vaccinia recombinants encoding $\mathrm{HeV} F$ and $\mathrm{HeV} G$ or $\mathrm{NiV} F$ and NiV G glycoproteins, along with a vaccinia recombinant encoding T7 RNA polymerase (effector cells). Each designated target cell type was infected with the $E$. coli LacZ-encoding reporter vaccinia virus vCB2IR. Each target cell type $\left(I \times I 0^{5}\right)$ was plated in duplicate wells of a 96-well plate. Inhibition was carried out using either the N-terminal (N-PEG-NiV FC2) or Cterminal (C-PEG-NiV FC2) pegylated and capped heptad peptides or C-terminal pegylated scrambled control peptide (C-PEG$\mathrm{ScNiV}$ FC2). Peptides were added to the $\mathrm{HeV}$ or NiV glycoprotein-expressing cells $\left(\mathrm{I} \times 10^{5}\right)$, incubated for $30 \mathrm{~min}$ at $37^{\circ} \mathrm{C}$, and then each target cell type was added The cell fusion assay was performed for $2.5 \mathrm{hr}$ at $37^{\circ} \mathrm{C}$, followed by lysis in Nonidet $\mathrm{P}-40(\mathrm{I} \%)$ and $\beta$-Gal activity was quantified. 


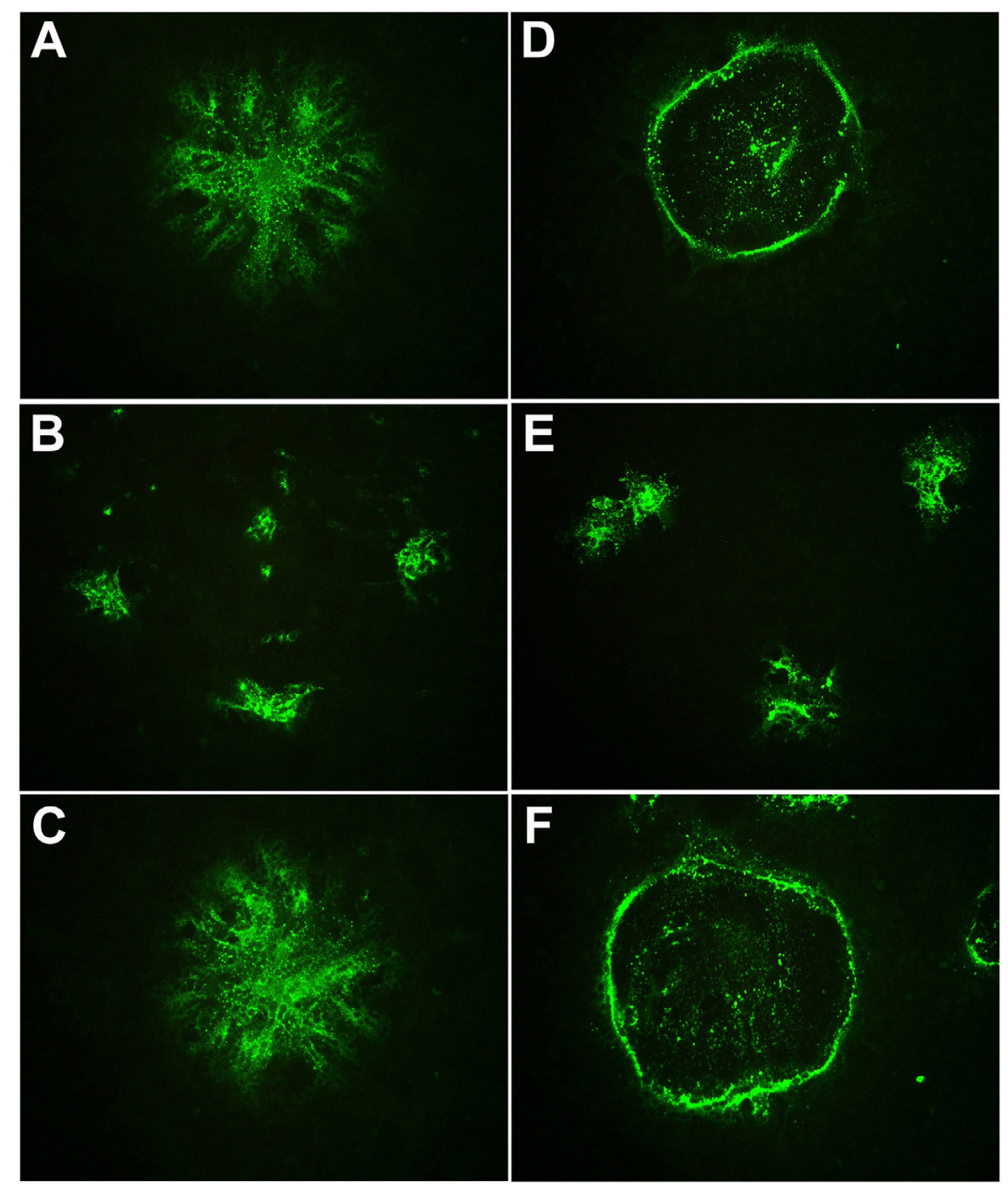

\section{Figure 4}

Immunofluorescence-based syncytia assay of Hendra virus and Nipah virus infection. Vero cells were plated into 96 well plates and grown to $90 \%$ confluence. Cells were pre-treated with heptad peptides for 30 min at $37^{\circ} \mathrm{C}$ prior to infection with $1.5 \times 10^{3} \mathrm{TCID}_{50} / \mathrm{ml}$ and $7.5 \times 10^{2} \mathrm{TCID}_{50} / \mathrm{ml}$ of live $\mathrm{HeV}$ or NiV (combined with peptide). Cells were incubated for 24 hours, fixed in methanol and immunofluorescently stained for $\mathrm{P}$ protein prior to digital microscopy. Images were obtained using an Olympus IX7I inverted microscope coupled to an Olympus DP70 high resolution color camera and all images were obtained at an original magnification of $85 \times$. Representative images of FITC immunofluorescence of anti-P labeled $\mathrm{HeV}$ and $\mathrm{NiV}$ syncytia are shown. A: HeV without peptide. B: HeV with C-PEG-NiV FC2. C: HeV with N-PEG-ScNiV FC2. D: NiV without peptide. E: NiV with N-PEG-NiV FC2. F: NiV with N-PEG-ScNiV FC2. 


\section{Hendra virus}
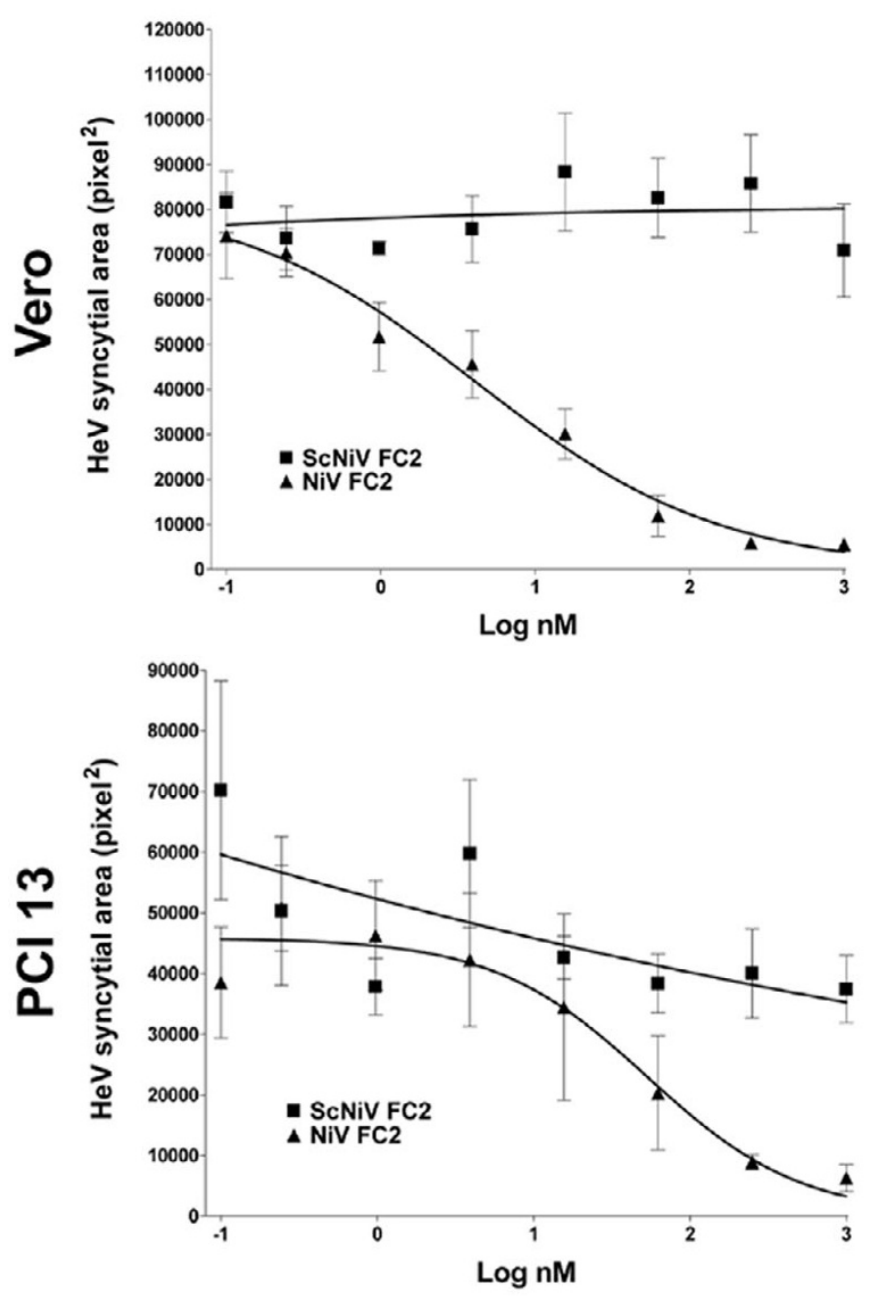

Nipah virus
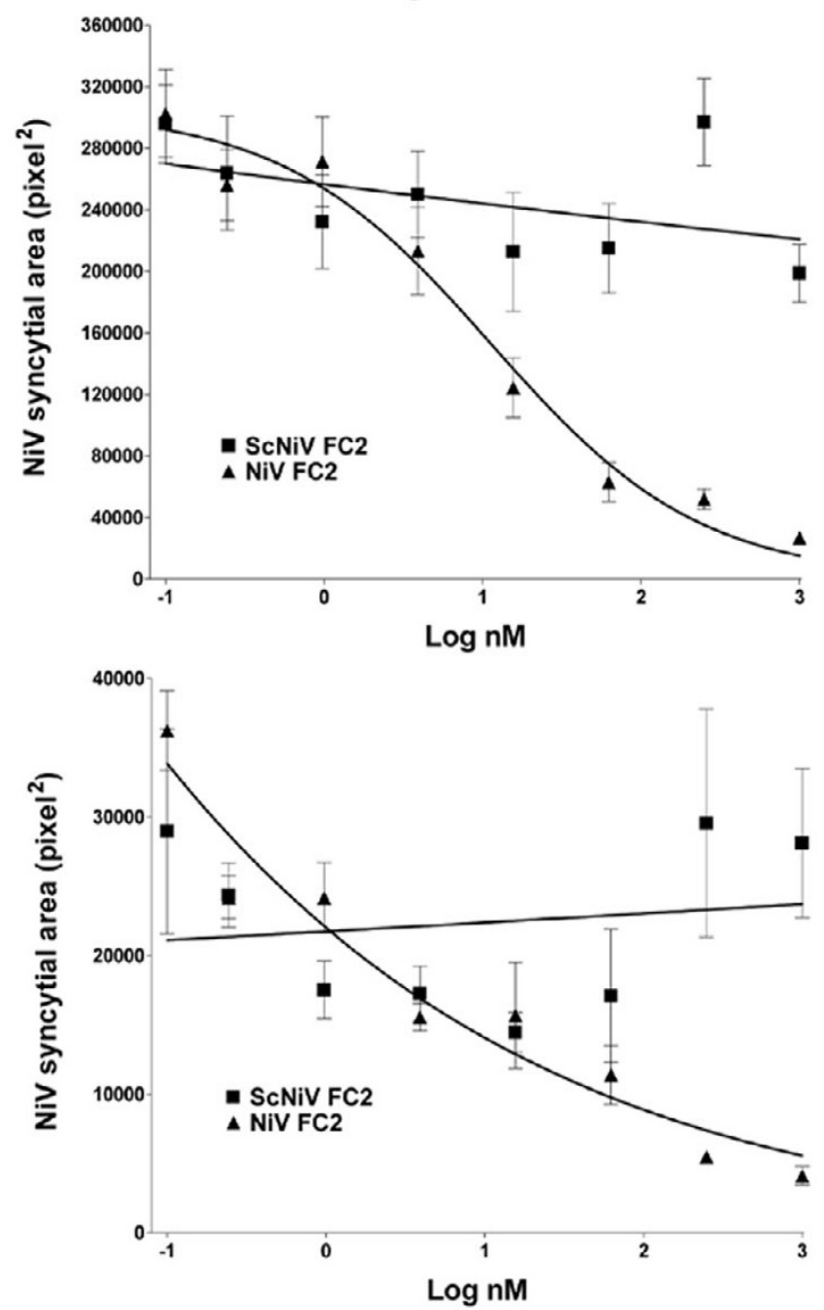

Figure 5

Inhibition of Hendra virus and Nipah virus infection by capped heptad peptides. Vero cells or PCI 13 cells were plated into 96 well plates and grown to $90 \%$ confluence. Cells were pre-treated with the indicated peptide for 30 min at $37^{\circ} \mathrm{C}$ prior to infection with $1.5 \times 10^{3} \mathrm{TCID}_{50} / \mathrm{ml}$ and $7.5 \times 10^{2} \mathrm{TCID}_{50} / \mathrm{ml}$ of live $\mathrm{HeV}$ or NiV (combined with peptide). Cells were incubated for 24 hours, fixed in methanol and immunofluorescently labeled for $\mathrm{P}$ protein prior to digital microscopy and image analysis to determine the relative area of each syncytium (see Methods). The figure shows the relative syncytial area (pixel2) versus the indicated peptide concentration for $\mathrm{HeV}$ and $\mathrm{NiV}$.

the N-PEG-NiV FC2. The N-PEG-NiV FC2 peptide had considerable potency against both $\mathrm{NiV}$ and $\mathrm{HeV}$ and the calculated $\mathrm{IC}_{50}$ values for inhibiting either virus on both cell lines ranged from $0.46 \mathrm{nM}$ to $2.05 \mathrm{nM}$ (Table 1 ).

\section{Discussion}

Both $\mathrm{NiV}$ and $\mathrm{HeV}$ continue to re-emerge, and in early 2004 two NiV outbreaks in Bangladesh have been confirmed totalling some 53 human cases of infection, and $\mathrm{HeV}$ has reappeared in Northern Australia in late 2004 with two cases of fatal infection in horses and one nonfatal human case [50]. The most recent NiV occurrence has again appeared in Bangladesh in January of 2005 [51]. Several important observations in these most recent outbreaks of $\mathrm{NiV}$ have been made, including a higher incidence of acute respiratory distress syndrome, person-toperson transmission occurring in the majority of cases, and significantly higher case fatality rates (60-75\%), and no direct link to infected livestock or domestic animals [8$12,51]$. In particular, the availability of $\mathrm{NiV}$ in the 

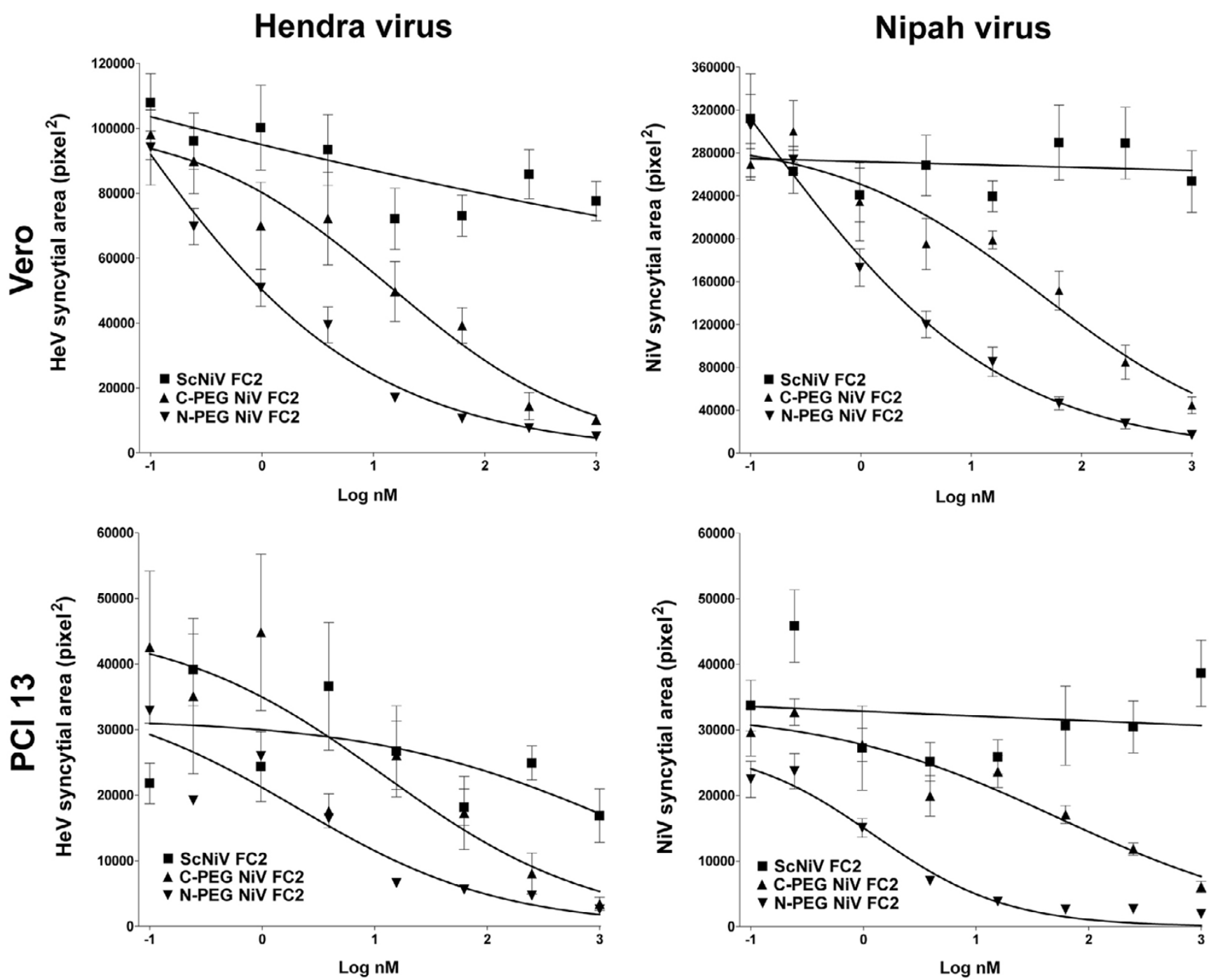

Figure 6

Inhibition of Hendra virus and Nipah virus infection by $\mathbf{N}$-terminal and $\mathbf{C}$-terminal pegylated heptad peptides. Vero cells or $\mathrm{PCl} I 3$ cells were plated into 96 well plates and grown to $90 \%$ confluence. Cells were pre-treated with the indicated peptide for $30 \mathrm{~min}$ at $37^{\circ} \mathrm{C}$ prior to infection with $1.5 \times 10^{3} \mathrm{TCID}_{50} / \mathrm{ml}$ and $7.5 \times 10^{2} \mathrm{TCID}_{50} / \mathrm{ml}_{\text {of }} \mathrm{live} \mathrm{HeV}$ or NiV (combined with peptide). Cells were incubated for 24 hours, fixed in methanol and immunofluorescently labeled for $\mathrm{P}$ protein prior to digital microscopy and image analysis to determine the relative area of each syncytium (see Methods). The figure shows the relative syncytial area (pixel ${ }^{2}$ ) versus the indicated peptide concentration for $\mathrm{HeV}$ and $\mathrm{NiV}$.

environment and the ability to grow the virus to high titer in the laboratory, it is also now considered a potential biological terror agent. Taken together these observations highlight the need to explore therapeutic strategies for henipaviruses. While there is some evidence that ribavirin therapy may be of clinical benefit [52], there are currently no other specific treatment options and only supportive care is indicated.
Paramyxoviruses, like retroviruses, possess a class I membrane fusion mechanism, and there have been major recent advances in the understanding of the structural requirements and mechanisms involved in the fusion process mediated by these viruses (reviewed in [19,5355]). The present model of class I membrane fusion describes the formation of a trimer-of-hairpins structure whose oligomeric coiled-coil formation is mediated by the $2 \alpha$-helical heptad repeat domains of the fusion glycoprotein which drives membrane fusion. Peptides 
corresponding to either of these heptad domains block fusion by interfering with the formation of the trimer-ofhairpins structure, first noted with sequences derived from the gp4 1 subunit of the HIV-1 envelope glycoprotein $[56,57]$. HIV-1 heptad-peptides have now met with clinical success and are the first approved fusion inhibitor therapeutics for a viral infection. Peptide sequences from either the $\mathrm{N}$ or $\mathrm{C}$ heptads of the $\mathrm{F}$ glycoprotein from a variety of paramyxoviruses have also been shown to inhibit fusion [28-33,58]. Previously, we demonstrated that fusion-inhibiting peptides corresponding to the C-terminal heptad repeat domain of the F glycoprotein of either $\mathrm{HeV}$ or NiV could potently inhibit the membrane fusion activity of either virus $[25,34]$. Because the peptides derived from the HR-2 of NiV F could inhibit both $\mathrm{HeV}$ and NiV-mediated fusion, in this study we only pursued peptides derived from NiV F. Furthermore, we have refined our initial peptide fusion inhibitors by reducing their length and chemically modifying their amino and carboxyl termini either by amidation or acetylation or through the addition of a PEG $_{10}$ moiety, and have examined these new peptides in both membrane fusion and virus infection assays.

We have demonstrated that Henipavirus-mediated fusion and infection can be potently inhibited by these chemically modified peptides in vitro in a dose-dependent fashion. Overall, the $\mathrm{IC}_{50}$ concentrations of the peptides in the present study were similar to our previous observations on un-capped 42-mer peptides against $\mathrm{HeV}$ and NiVmediated cell-cell fusion as well as to those observed in other paramyxovirus and retrovirus systems. However, we found that the N-terminal pegylated NiV FC2 peptide used here to be particularly potent with overall $\mathrm{IC}_{50}$ values of $<10 \mathrm{nM}$ for both $\mathrm{HeV}$ and $\mathrm{NiV}$ cell-cell fusion and virus infection. The present results indicate that both the capped and pegylated peptides are equally as effective as the unmodified first generation fusion-inhibiting peptides. Interestingly, peptides with the $\mathrm{PEG}_{10}$ moiety linked to the $\mathrm{C}$-terminus were slightly, yet reproducibly, less effective than N-terminal pegylated peptides. We speculate that this could reflect some process of steric hindrance effect by the $P \mathrm{GG}_{10}$ moiety in interacting with the $\mathrm{F}$ glycoprotein during its conformational alteration leading to 6-helix bundle formation.

These same chemical modifications also improved the solubility characteristics of the heptad-derived peptides, and also significantly increased the yield during synthesis and purification (data not shown). The primary objectives of the present study were to demonstrate that these peptides possessed potent inhibitory activity in surrogate viral glycoprotein-mediated membrane fusion assays as well as in live virus infection assays, and improve peptide solubility and synthesis yields. The specific chemical modifications were chosen, especially pegylation, to help improve the plasma half-life and thus enhance therapeutic success. Covalent coupling of PEG to proteins or "pegylation" is currently considered one of the most successful techniques to prolong the residence time of protein drugs in the bloodstream [47,59-61]. PEG is a water soluble polymer that when covalently linked to molecules, conveys its physico-chemical properties and therefore modifies the biodistribution and solubility of peptide and non-peptide drugs. Additionally, pegylation masks the peptide's surface and increases the molecular size of the polypeptide, thus reducing its renal ultrafiltration. PEG modification can also prevent the approach of antibodies or antigen processing cells and reduce their degradation by proteolytic enzymes [62].

\section{Conclusion}

The isolation of four new members of the family Paramyxoviridae in the past 10 years in addition to several largely uncharacterised paramyxoviruses recovered from historical rodent and snake sampling may indicate a much larger than previously thought, reservoir of paramyxoviruses. Given the success of heptad-derived peptide inhibition of paramyxovirus fusion, many of these new and yet to be discovered viruses may well be inherently treatable, such that the possibility of antiviral therapy may be available as soon as a sequence has been obtained for the respective fusion envelope glycoprotein. We are presently evaluating the properties of these anti-HeV and $\mathrm{NiV}$ fusion inhibiting peptides as well as their potential therapeutic value with an in vivo model of virus infection.

\section{Methods \\ Cells and Culture conditions}

HeLa cells (ATCC CCL 2) and African green monkey (Vero) cells (ATCC CCL 81) were obtained from the American Type Culture Collection. A HeLa cell line derivative (HeLa-USU) which does not express the NiV and $\mathrm{HeV}$ receptor, ephrin-B2 [13] was provided by Anthony Maurelli, USUHS, Bethesda, MD. The human glioblastoma cell line U373-MG was provided by Adam P. Geballe, Fred Hutchinson Cancer Research Center, Seattle, WA [63]. The human head and neck carcinoma PCI 13 cell line was the kind gift of Ernest Smith, Vaccinex, Inc. HeLa and U373 cell monolayers were maintained in Dulbecco's modified Eagle's medium supplemented with $10 \%$ cosmic calf serum (CCS) (Hyclone, Logan, UT) and $2 \mathrm{mM}$ L-glutamine (DMEM-10). PCI 13 cell monolayers were maintained in DMEM-10 supplemented with $1 \mathrm{mM}$ HEPES. Vero cells were maintained in the absence of antibiotics in Minimal Essential Medium containing Earle's salts and $10 \%$ fetal calf serum (EMEM-10). All cell cultures were maintained at $37^{\circ} \mathrm{C}$ under a humidified $5 \%$ $\mathrm{CO} 2$ atmosphere. 


\section{Viruses}

For expression of recombinant $\mathrm{HeV}$ and NiV F and G glycoproteins, the following recombinant vaccinia viruses were employed: vKB7 (NiV F), vKB6 (NiV G), vKB1 ( HeV F), vKB2 (HeV G) $[25,34,64]$. Bacteriophage T7 RNA polymerase was produced by infection with vTF7-3 which contains the T7 RNA polymerase gene linked to a vaccinia virus promoter [65]. The E. coli lacZ gene linked to the T7 promoter was introduced into cells by infection with vaccinia virus recombinant vCB21R-LacZ, which was described previously [66]. HeV stock virus (titer $1 \times 10^{8}$ $\mathrm{TCID}_{50} / \mathrm{ml}$ ) was prepared as described [67]. NiV stock virus (titer $3 \times 10^{7} \mathrm{TCID}_{50} / \mathrm{ml}$ ) was prepared as described [68].

\section{Cell-fusion assays}

Fusion between envelope glycoprotein-expressing and target cells was measured by a reporter gene assay in which the cytoplasm of one cell population contained vaccinia virus-encoded T7 RNA polymerase and the cytoplasm of the other contained the E. coli lacZ gene linked to the T7 promoter; $\beta$-galactosidase $(\beta$-Gal) is synthesized only in fused cells $[35,69]$. Vaccinia virus-encoded proteins were produced by infecting cells (moi $=10$ ) and incubating infected cells at $31^{\circ} \mathrm{C}$ overnight. Cell-fusion reactions were conducted with the various cell mixtures in 96-well plates at $37^{\circ} \mathrm{C}$. Typically, the ratio of envelope glycoprotein-expressing cells to target cells was $1: 1\left(2 \times 10^{5}\right.$ total cells per well, 0.2-ml total volume). Cytosine arabinoside $(40 \mu \mathrm{g} / \mathrm{ml})$ was added to the fusion reaction mixture to reduce non-specific $\beta$-Gal production [35]. For quantitative analyses, Nonidet P-40 was added ( $0.5 \%$ final) at 2.5 $\mathrm{h}$ and aliquots of the lysates were assayed for $\beta$-Gal at ambient temperature with the substrate chlorophenol red-D-galactopyranoside (CPRG; Roche Diagnostics Corp.). For inhibition by peptides, serial dilutions of peptides were performed and added to effector cell populations prior to the addition of target cell populations. All assays were performed in duplicate and fusion results were calculated and expressed as rates of $\beta$-Gal activity (change in optical density at $570 \mathrm{~nm}$ per minute $\times 1,000$ ).

\section{Virus infection assay and immunofluorescence}

Vero cells were seeded into 96 well plates at $6 \times 10^{4}$ cells/ $300 \mu \mathrm{l}$ and grown to $90 \%$ confluence in EMEM-10 at $37^{\circ} \mathrm{C}$ under a humidified 5\% CO2 atmosphere. Peptides were diluted 4-fold in EMEM. Under biohazard level 4 conditions, media were discarded and $100 \mu$ l of diluted virus was added to each well and incubated at $37^{\circ} \mathrm{C}$ for 30 min. Virus dilutions were chosen to generate 50 plaques under these adsorption conditions. Virus inoculum was removed and $200 \mu \mathrm{l}$ of diluted peptide was added to each well and incubated at $37^{\circ} \mathrm{C}$ for $18 \mathrm{~h}$. The culture medium was discarded and plates were immersed in ice-cold absolute methanol for at least 20 min prior to air-drying out- side the biohazard level 4 facility. Fixed plates were immunolabeled with anti-P monospecific antisera [70]. Briefly, slides were washed in $0.01 \mathrm{M}$ phosphate-buffered saline (PBS), pH 7.2 containing 1\% BSA for 5 min. $40 \mu \mathrm{l}$ of anti-P antiserum (1:200 in PBS-BSA) was applied to each well and incubated at $37^{\circ} \mathrm{C}$ for $30 \mathrm{~min}$. Slides were rinsed with PBS containing 0.05\% Tween 20 (PBS-T) and washed for $5 \mathrm{~min}$ in PBS-BSA. $40 \mu \mathrm{l}$ of FITC labeled goat anti-rabbit antiserum (ICN Pharmaceuticals, Costa Mesa, USA) diluted 1:100 in PBS-BSA was then applied to each well and incubated at $37^{\circ} \mathrm{C}$ for $30 \mathrm{~min}$. Slides were rinsed again with PBS containing 0.05\% Tween 20 (PBS-T) and washed for $5 \mathrm{~min}$ in PBS-BSA. Wells were overlaid with glycerol/PBS (1:1) containing DABCO (25 ug/ml) and stored in the dark prior to imaging.

FITC immunofluorescence was visualized using an Olympus IX71 inverted microscope (Olympus Australia, Mt. Waverley, Australia) coupled to an Olympus DP70 high resolution color camera. Image analysis was performed using AnalySIS ${ }^{\circledast}$ image analysis software (Soft Imaging System GmbH, Munster, Germany). Briefly, individual virus syncytia were detected by threshold analysis followed by "hole filling" and subsequently measured to determine the area of each syncytium. To ensure repeatability between images, all procedures were performed as a macro function with fixed parameters. Nine images were analysed for each peptide concentration resulting in the collation of syncytial area data for between 9-36 foci per peptide concentration (average 15). Measurements were collated and non-linear regression analysis performed using GraphPad Prism software (GraphPad Software, San Diego, CA USA) to determine the $\mathrm{IC}_{50}$.

\section{Peptide synthesis}

The following peptide sequence, corresponding to the Cterminal $\alpha$-helical heptad repeat domain (HR-2) of the NiV F glycoprotein, was chosen for synthesis: KVDISSQISSMNQSLQQSKDYIKEAQRLLDTVNPSL (NiV FC2). A scrambled version of the 36-amino-acid peptide was also synthesized for use as a negative control KQSSMISLQSQKSINSLPSQIRDYVQKTVLLAEDND (ScNiV FC2).

All peptides were synthesized utilizing the Fmoc/tBu protection scheme. The peptides with PEG $\left({ }_{10}\right)$ on the N-terminus were synthesized on a PS3 automated synthesizer (Protein Technologies Inc., Tucson, AZ) using NovaSYN ${ }^{\circledR}$ TGR Resin (Nova Biochem, EMD Biosciences, Inc. La Jolla, CA). The peptides with PEG $\left.{ }_{10}\right)$ on the C-terminus were synthesized on an ABI433 automated synthesizer (Applied Biosystems, Foster City, CA) using 2-Chlorotrityl resin (Nova Biochem). The protected amino acids were incorporated into the peptide via active ester formation using 2-(6-Chloro-1H-benzotriazole-1-yl)-1,1,3,3tetramethyluronium hexafluorophosphate (HCTU) 
(Nova Biochem). All Fmoc protected amino acids were supplied by Nova Biochem. The protecting groups used were as follows: sidechains of Asn, Cys, His, and Gln were protected with Trityl (trt), Glu and Ser were protected with tert-Butyl (tBu), Lys was protected with tert-Butyloxycarbonyl (Boc),Arg was protected with 2,2,4,6,7-pentamethyldihydrobenzopfuran-5-sulfonyl (Pbf). Ala, Leu, Phe, Val, and Gly were used without sidechain protection. PEG $_{(10)}$ was incorporated using $\mathrm{O}$-(N-Fmoc-2-aminoethyl)-O'-(2carboxyethyl)-undecaethyleneglycol (Nova Biochem) and the peptides were acetylated by treatment with acetic anhydride (Sigma-Aldrich). Peptides were cleaved from the solid support using 92\% trifluoacetic acid (Halocarbon), $2 \%$ anisole, $2 \%$ ethanedithiol, $2 \%$ triisopropylsilane (all Sigma-Aldrich), and 2\% water. Peptides were purified on a Waters 600e semi-prep HPLC system using a grace Vydac 300. Diphenyl column and solvents $0.1 \% \mathrm{TFA} /$ water $(\mathrm{A})$ and $0.1 \% \mathrm{TFA} /$ acetonitrile (ACN) (B). Analytical HPLC analysis of all fractions was performed using a Waters Alliance 2695 with a $2.1 \times 30 \mathrm{~mm}$ Symmetry Shield ${ }^{\mathrm{TM}} \mathrm{RP} 183.5 \mathrm{~m}$ column. Matrix assisted laser desorption/ionization time of flight (MALDI-ToF) mass spec analysis of the crude and pure peptides was performed using an ABI Voyager DE Pro system. Crude peptide from each synthesis and pure peptide was dissolved in $50 \% \mathrm{ACN} /$ water and spotted with $\alpha$-Cyano-4-Hydroxycinnimic Acid matrix (Sigma-Aldrich). Positive ions were detected using the linear detector, which is calibrated with Bradykinin and Angiotensin standards.

\section{Proteomics computational methods}

Methods to derive general models of surface glycoproteins have been described previously [43]. Homology modelling of Hendra virus and Nipah virus $\mathrm{F}$ was based on the structure of the $\mathrm{F}$ protein of Newcastle disease virus, another member of the Paramyxoviridae, determined by x-ray crystallography [40]. MacMolly (Soft Gene GmbH, Berlin) was used to locate areas of sequence similarity and to perform alignments. PHDsec (Columbia University Bioinformatics Center, http://cubic.bioc.columbia.edu/ predictprotein/) was used for secondary structure prediction [41]. PHDsec predicts secondary structure from multiple sequence alignments by a system of neural networks, and is rated at an expected average accuracy of $72 \%$ for three states, helix, strand and loop. Domains with significant propensity to form transmembrane helices were identified with TMpred (ExPASy, Swiss Institute of Bioinformatics, $\quad$ http://www.ch.embnet.org/software/ TMPRED form.html). TMpred is based on a statistical analysis of TMbase, a database of naturally occurring transmembrane glycoproteins [42].

\section{Competing interests}

The author(s) declare that they have no competing interests.

\section{Authors' contributions}

KNB conceived and contributed to the design and use of heptad derived peptides as fusion inhibitors henipaviruses, designed and carried out all cell-fusion assays, interpreted data, and edited and corrected the manuscript. BAM and GC developed and carried out all live virus infections and peptide inhibition assays, interpreted data and edited and corrected the manuscript. LFW provided financial support, corrected the manuscript and provided supervision of KNB. BTE provided expertise for conducting the live virus infection experiments, financial support, corrected the manuscript and provided supervision of BAM and GC. CCB conceived and contributed to design and use of heptad derived peptides as fusion inhibitors for henipaviruses and PEG-linked versions of peptides, provided overall supervision and financial support and prepared the final versions of the manuscript.

\section{Acknowledgements}

We wish to especially thank Robert F. Garry, Tulane University Health Sciences Center, and William R Gallaher, Louisiana State University Medical Center, for modeling the Nipah and Hendra virus FI glycoprotein. We also wish to acknowledge the excellent technical assistance and service provided by John Phipps and Ron Donoho of Global Peptide Services, Inc. We also especially thank Thomas Matthews of Trimeris Inc., for advice and consultation and whose help will be particularly missed due to his untimely death. The views expressed in the manuscript are solely those of the authors, and they do not represent official views or opinions of the Department of Defence or the Uniformed Services University. This study was supported by NIH AI056423 grant to C.C.B.

\section{References}

I. Murray K, Selleck P, Hooper P, Hyatt A, Gould A, Gleeson L, Westbury H, Hiley L, Selvey L, Rodwell B, et al.: A morbillivirus that caused fatal disease in horses and humans. Science 1995 , 268:94-97.

2. Chua KB, Goh KJ, Wong KT, Kamarulzaman A, Tan PS, Ksiazek TG, Zaki SR, Paul G, Lam SK, Tan CT: Fatal encephalitis due to Nipah virus among pig-farmers in Malaysia [see comments]. Lancet 1999, 354:1257-1259.

3. Barclay AJ, Paton DJ: Hendra (equine morbillivirus). Vet ] 2000 160:169-176.

4. Wong KT, Shieh WJ, Kumar S, Norain K, Abdullah W, Guarner J, Goldsmith CS, Chua KB, Lam SK, Tan CT, Goh KJ, Chong HT, Jusoh R, Rollin PE, Ksiazek TG, Zaki SR: Nipah virus infection: pathology and pathogenesis of an emerging paramyxoviral zoonosis. Am J Pathol 2002, I6 I:2 I53-2167.

5. Wang LF, Yu M, Hansson E, Pritchard LI, Shiell B, Michalski WP, Eaton BT: The exceptionally large genome of Hendra virus: support for creation of a new genus within the family Paramyxoviridae. J Virol 2000, 74:9972-9979.

6. Wang L, Harcourt BH, Yu M, Tamin A, Rota PA, Bellini WJ, Eaton BT: Molecular biology of Hendra and Nipah viruses. Microbes Infect 200I, 3:279-287.

7. Field $\mathrm{H}$, Young $\mathrm{P}$, Yob JM, Mills J, Hall L, Mackenzie J: The natural history of Hendra and Nipah viruses. Microbes Infect 200I, 3:307-3 I 4 .

8. Enserink $M$ : Emerging infectious diseases. Nipah virus (or a cousin) strikes again. Science 2004, 303: I I 21.

9. Anonymous: Nipah virus outbreak(s) in Bangladesh, JanuaryApril 2004. Wkly Epidemiol Rec 2004, 79: 168-171.

10. Butler D: Fatal fruit bat virus sparks epidemics in southern Asia. Nature 2004, 429:7.

II. Anonymous: Vol. 2 No. 2 June 2004 Person-to-person transmission of Nipah virus during outbreak in Faridpur District, 2004. Health and Science Bulletin (ICDDR,B) 2004, 2:5-9. 
12. Hsu VP, Hossain MJ, Parashar UD, Ali MM, Ksiazek TG, Kuzmin I, Niezgoda M, Rupprecht C, Bresee J, Breiman RF: Nipah Virus Encephalitis Reemergence, Bangladesh. Emerg Infect Dis 2004, I 0:2082-2087.

13. Bonaparte MI, Dimitrov AS, Bossart KN, Crameri G, Mungall BA, Bishop KA, Choudhry V, Dimitrov DS, Wang LF, Eaton BT, Broder CC: Ephrin-B2 Ligand is a Functional Receptor for Hendra Virus and Nipah Virus. Proc Natl Acad Sci U S A 2005, In Press:.

14. Baker KA, Dutch RE, Lamb RA, Jardetzky TS: Structural basis for paramyxovirus-mediated membrane fusion. Mol Cell 1999 3:309-319.

15. Lamb RA, Kolakofsky D: Paramyxoviridae: The viruses and their replication. In Fields Virology 4th edition. Edited by: Knipe DM and Howley PM. Philadelphia, Lippincott Williams \& Wilkins; 2001:1305-1340.

16. Scheid A, Choppin PW: Two disulfide-linked polypeptide chains constitute the active $\mathbf{F}$ protein of paramyxoviruses. Virology 1977, 80:54-66

17. Klenk HD, Garten W: Host cell proteases controlling virus pathogenicity. Trends Microbiol I 994, 2:39-43.

18. Earp LJ, Delos SE, Park HE, White JM: The many mechanisms of viral membrane fusion proteins. Curr Top Microbiol Immunol 2005, 285:25-66.

19. Weissenhorn W, Dessen A, Calder LJ, Harrison SC, Skehel JJ, Wiley DC: Structural basis for membrane fusion by enveloped viruses. Mol Membr Biol 1999, 16:3-9.

20. Chan DC, Kim PS: HIV entry and its inhibition. Cell 1998, 93:68I-684

21. Skehel JJ, Wiley DC: Coiled coils in both intracellular vesicle and viral membrane fusion. Cell I998, 95:87 I-874.

22. Singh M, Berger B, Kim PS: LearnCoil-VMF: computational evidence for coiled-coil-like motifs in many viral membranefusion proteins. J Mol Biol 1999, 290:1031-I04I

23. Hughson FM: Enveloped viruses: a common mode of membrane fusion? Curr Biol I997, 7:R565-9.

24. Xu Y, Gao S, Cole DK, Zhu J, Su N, Wang H, Gao GF, Rao Z: Basis for fusion inhibition by peptides: analysis of the heptad repeat regions of the fusion proteins from Nipah and Hendra viruses, newly emergent zoonotic paramyxoviruses. Biochem Biophys Res Commun 2004, 3 I 5:664-670.

25. Bossart KN, Wang LF, Eaton BT, Broder CC: Functional expression and membrane fusion tropism of the envelope glycoproteins of Hendra virus. Virology 200I, 290: I II-I35.

26. Chambers $P$, Pringle CR, Easton AJ: Heptad repeat sequences are located adjacent to hydrophobic regions in several types of virus fusion glycoproteins. J Gen Virol 1990, 7 I:3075-3080.

27. Xu Y, Lou Z, Liu Y, Cole DK, Su N, Qin L, Li X, Bai Z, Rao Z, Gao GF: Crystallization and preliminary crystallographic analysis of the fusion core from two new zoonotic paramyxoviruses, Nipah virus and Hendra virus. Acta Crystallogr D Biol Crystallogr 2004, 60: I 16I-I I64.

28. Lambert DM, Barney S, Lambert AL, Guthrie K, Medinas R, Davis DE, Bucy T, Erickson J, Merutka G, Petteway SRJ: Peptides from conserved regions of paramyxovirus fusion (F) proteins are potent inhibitors of viral fusion. Proc Natl Acad Sci U S A 1996 , 93:2186-2191

29. Joshi SB, Dutch RE, Lamb RA: A core trimer of the paramyxovirus fusion protein: parallels to influenza virus hemagglutinin and HIV-I gp4 I. Virology 1998, 248:20-34.

30. Wild TF, Buckland R: Inhibition of measles virus infection and fusion with peptides corresponding to the leucine zipper region of the fusion protein. J Gen Virol I997, 78: I07-I I I.

31. Young JK, Li D, Abramowitz MC, Morrison TG: Interaction of peptides with sequences from the Newcastle disease virus fusion protein heptad repeat regions. J Virol 1999, 73:5945-5956.

32. Young JK, Hicks RP, Wright GE, Morrison TG: Analysis of a peptide inhibitor of paramyxovirus (NDV) fusion using biological assays, NMR, and molecular modeling. Virology 1997, 238:291-304.

33. Rapaport D, Ovadia M, Shai Y: A synthetic peptide corresponding to a conserved heptad repeat domain is a potent inhibitor of Sendai virus-cell fusion: an emerging similarity with functional domains of other viruses. Embo $J$ 1995, | 4:5524-553 |

34. Bossart KN, Wang LF, Flora MN, Chua KB, Lam SK, Eaton BT, Broder $C C$ : Membrane fusion tropism and heterotypic functional activities of the nipah virus and hendra virus envelope glycoproteins. J Virol 2002, 76: I I I86- I I I98

35. Bossart KN, Broder CC: Viral glycoprotein-mediated cell fusion assays using vaccinia virus vectors. Methods $\mathrm{Mol}$ Bio 2004, 269:309-332

36. Weiss CD: HIV-I gp4I: mediator of fusion and target for inhibition. AIDS Rev 2003, 5:2I4-22I.

37. Kilby JM, Hopkins S, Venetta TM, DiMassimo B, Cloud GA, Lee JY, Alldredge L, Hunter E, Lambert D, Bolognesi D, Matthews T, Johnson MR, Nowak MA, Shaw GM, Saag MS: Potent suppression of HIVI replication in humans by $\mathbf{T}-20$, a peptide inhibitor of gp 4 I mediated virus entry. Nat Med 1998, 4: I302-I307.

38. Kilby JM, Lalezari JP, Eron JJ, Carlson M, Cohen C, Arduino RC, Goodgame JC, Gallant JE, Volberding P, Murphy RL, Valentine F, Saag MS, Nelson EL, Sista PR, Dusek A: The safety, plasma pharmacokinetics, and antiviral activity of subcutaneous enfuvirtide (T-20), a peptide inhibitor of gp 41 -mediated virus fusion, in HIV-infected adults. AIDS Res Hum Retroviruses 2002, 18:685-693.

39. Rockstroh JK, Mauss S: Clinical perspective of fusion inhibitors for treatment of HIV. J Antimicrob Chemother 2004, 53:700-702.

40. Chen L, Gorman J], McKimm-Breschkin J, Lawrence LJ, Tulloch PA, Smith BJ, Colman PM, Lawrence MC: The structure of the fusion glycoprotein of Newcastle disease virus suggests a nove paradigm for the molecular mechanism of membrane fusion. Structure (Camb) 200I, 9:255-266.

4I. Rost B, Liu J: The PredictProtein server. Nucleic Acids Res 2003 3 I:3300-3304.

42. Hofmann K, Stoffel W: TMbase - A database of membrane spanning proteins segments. Biol Chem Hoppe-Seyler 1993, 374: 166 .

43. Gallaher WR, Ball JM, Garry RF, Griffin MC, Montelaro RC: A general model for the transmembrane proteins of HIV and other retroviruses [see comments]. AIDS Res Hum Retroviruses 1989, 5:43|-440.

44. Gallaher WR, Ball JM, Garry RF, Martin-Amedee AM, Montelaro RC: A general model for the surface glycoproteins of HIV and other retroviruses. AIDS Res Hum Retroviruses 1995, | |: | 9|-202.

45. Earl PL, Broder CC, Doms RW, Moss B: Epitope map of human immunodeficiency virus type I gp4I derived from 47 monoclonal antibodies produced by immunization with oligomeric envelope protein. J Virol 1997, 7 I:2674-2684.

46. Harcourt BH, Tamin A, Ksiazek TG, Rollin PE, Anderson LJ, Bellin WJ, Rota PA: Molecular characterization of Nipah virus, a newly emergent paramyxovirus. Virology 2000, 27 I:334-349.

47. Harris JM, Martin NE, Modi M: Pegylation: a novel process for modifying pharmacokinetics. Clin Pharmacokinet 200I, 40:539-551.

48. Francis GE, Fisher D, Delgado C, Malik F, Gardiner A, Neale D PEGylation of cytokines and other therapeutic proteins and peptides: the importance of biological optimisation of coupling techniques. Int I Hematol 1998, 68: I- I8.

49. Hyatt AD, Zaki SR, Goldsmith CS, Wise TG, Hengstberger SG: Ultrastructure of Hendra virus and Nipah virus within cultured cells and host animals. Microbes Infect 200I, 3:297-306.

50. Anonymous: Hendra Virus - Australia (Queensland). In Pro-med , International Society for Infectious Diseases; 2004.

5I. Anonymous: Emerging Infections update: November 2004 to January 2005. Communicable Disease Report Weekly (CDR Weekly) 2005, I5:

52. Chong HT, Kamarulzaman A, Tan CT, Goh KJ, Thayaparan T, Kunjapan SR, Chew NK, Chua KB, Lam SK: Treatment of acute Nipah encephalitis with ribavirin. Ann Neurol 200I, 49:810-813.

53. Dimitrov DS: Cell biology of virus entry. Cell 2000, 10 I:697-702.

54. Russell C], Jardetzky TS, Lamb RA: Membrane fusion machines of paramyxoviruses: capture of intermediates of fusion. Embo 200I, 20:4024-4034.

55. Eckert DM, Kim PS: Mechanisms of Viral Membrane Fusion and Its Inhibition. Annu Rev Biochem 200I, 70:777-8I0.

56. Wild CT, Shugars DC, Greenwell TK, McDanal CB, Matthews T]: Peptides corresponding to a predictive alpha-helical domain of human immunodeficiency virus type I gp4I are potent inhibitors of virus infection. Proc Natl Acad Sci U S A 1994, 91:9770-9774.

57. Jiang $S$, Lin K, Strick N, Neurath AR: HIV-I inhibition by a peptide. Nature 1993, 365: II3. 
58. Young JK, Hicks RP, Wright GE, Morrison TG: The role of leucine residues in the structure and function of a leucine zipper peptide inhibitor of paramyxovirus (NDV) fusion. Virology |998, 243:2|-3|.

59. Delgado C, Pedley RB, Herraez A, Boden R, Boden JA, Keep PA, Chester KA, Fisher D, Begent RH, Francis GE: Enhanced tumour specificity of an anti-carcinoembrionic antigen Fab' fragment by poly(ethylene glycol) (PEG) modification. $\mathrm{Br} J$ Cancer 1996, 73:175-182.

60. Delgado C, Malik F, Selisko B, Fisher D, Francis GE: Quantitative analysis of polyethylene glycol (PEG) in PEG-modified proteins/cytokines by aqueous two-phase systems. J Biochem Biophys Methods 1994, 29:237-250.

61. Caliceti P, Veronese FM: Pharmacokinetic and biodistribution properties of poly(ethylene glycol)-protein conjugates. Adv Drug Deliv Rev 2003, 55:1261-1277.

62. Veronese FM: Peptide and protein PEGylation: a review of problems and solutions. Biomaterials 200I, 22:405-4I7.

63. Harrington RD, Geballe AP: Cofactor requirement for human immunodeficiency virus type I entry into a CD4-expressing human cell line. J Virol 1993, 67:5939-5947.

64. Bossart KN, Crameri G, Dimitrov AS, Mungall BA, Feng YR, Patch JR, Choudhary A, Wang LF, Eaton BT, Broder CC: Receptor binding, fusion inhibition, and induction of cross-reactive neutralizing antibodies by a soluble $g$ glycoprotein of hendra virus. J Virol 2005, 79:6690-6702.

65. Fuerst TR, Niles EG, Studier FW, Moss B: Eukaryotic transientexpression system based on recombinant vaccinia virus that synthesizes bacteriophage T7 RNA polymerase. Proc Natl Acad Sci USA 1986, 83:8I22-8I26.

66. Feng Y, Broder CC, Kennedy PE, Berger EA: HIV-I entry cofactor: functional cDNA cloning of a seven-transmembrane, G protein-coupled receptor. Science 1996, 272:872-877.

67. Wang LF, Michalski WP, Yu M, Pritchard LI, Crameri G, Shiell B, Eaton BT: A novel P/V/C gene in a new member of the Paramyxoviridae family, which causes lethal infection in humans, horses, and other animals. J Virol 1998, 72:1482-I490.

68. Crameri G, Wang LF, Morrissy C, White J, Eaton BT: A rapid immune plaque assay for the detection of Hendra and Nipah viruses and anti-virus antibodies. J Virol Methods 2002, 99:4I-5I.

69. Nussbaum O, Broder CC, Berger EA: Fusogenic mechanisms of enveloped-virus glycoproteins analyzed by a novel recombinant vaccinia virus-based assay quantitating cell fusiondependent reporter gene activation. J Virol I994, 68:54 I I-5422.

70. Michalski WP, Crameri G, Wang L, Shiell B], Eaton B: The cleavage activation and sites of glycosylation in the fusion protein of Hendra virus. Virus Res 2000, 69:83-93.

\section{Publish with Bio Med Central and every scientist can read your work free of charge}

"BioMed Central will be the most significant development for disseminating the results of biomedical research in our lifetime. "

Sir Paul Nurse, Cancer Research UK

Your research papers will be:

- available free of charge to the entire biomedical community

- peer reviewed and published immediately upon acceptance

- cited in PubMed and archived on PubMed Central

- yours - you keep the copyright
BioMedcentral 